OPEN ACCESS

Edited by:

Nikolaos P. Ventikos, National Technical University of Athens, Greece

Reviewed by:

Xiaoshou Liu,

Ocean University of China, China Mary Pothitos,

Independent Researcher, Greece

*Correspondence: Jhonnie M. Kern

jhonnie.kern@law.gu.se

Specialty section: This article was submitted to Marine Pollution,

a section of the journal Frontiers in Marine Science

Received: 30 October 2015 Accepted: 25 January 2016 Published: 25 February 2016

Citation:

Kern JM (2016) Wreck Removal and the Nairobi Convention-a Movement

Toward a Unified Framework?

Front. Mar. Sci. 3:11.

doi: 10.3389/fmars.2016.00011

\section{Wreck Removal and the Nairobi Convention-a Movement Toward a Unified Framework?}

\author{
Jhonnie M. Kern * \\ Department of Law, School of Business, Economics and Law, University of Gothenburg, Gothenburg, Sweden
}

The Nairobi International Convention on the Removal of Wrecks came into force on the 14th of April 2015 and provides a framework for wreck removal. Three central questions arise when dealing with shipwrecks; Who is responsible? What measures can and are to be taken based on such a responsibility? And lastly; how can the responsibility be enforced? The Nairobi Convention on the Removal of Wrecks addresses these questions. The registered owner of a ship bears strict liability according to the convention but can be exonerated by certain limited defenses. Measures that are to be taken include locating, marking, and subsequently removing the wreck. The onus to remove the wreck is on the registered owner, but there are also options available for the State affected by the wreck should the registered owner not cooperate or be unable to contact. Finally the convention strives to ensure enforceability by compulsory insurance for ships, wherever registered, with a gross tonnage of 300 tons and above calling any port or offshore facility in a State Party. The convention also enables an Affected State to claim the insurer directly. This article will analyze the convention by the use of the convention text, its preparatory works and legal writing. The article suggests that even though the convention provides a unified framework for wreck removal, it has inclusions that may actually inhibit harmonization. The convention is also in part unclear and ambiguous. Despite this the article concludes in the convention being a natural step forward in unifying the regulation of wrecks and providing a platform to deal with wreck removal in the future.

Keywords: wreck removal, Nairobi Convention, maritime law, shipwrecks

\section{INTRODUCTION}

Major wreck removal operations like the Costa Concordia and Tricolor have stirred an interest on the topic of wreck removal in different areas of research and among them the legal discipline. Indeed wreck removal has been the subject of discussion from a legal perspective for many years, but it is only of late that the discussions have resulted in regulation on an international level. This article will in some depth study the major convention on this area which is the Nairobi International Convention on the Removal of Wrecks (hereafter abbreviated as either the Nairobi Convention or $W R C$ ) and evaluate whether the convention is a way forward toward a unified regulation on wreck removal or not.

When dealing with wreck removal from a legal perspective three main questions need to be answered. The first question is: Who is responsible for a wreck? When the issue of responsibility has been addressed the next question is: What measures can and are to be taken based on that 
responsibility? These measures relate to how the wreck removal is to take place in practice. Last but not least remains the question: How can the responsibility be enforced? The mere existence of responsibility and measures that can and are to be taken are not worth much should there in practice be no possibility of enforcement. As will be shown the Nairobi Convention addresses these questions to various extents.

\section{MATERIALS AND METHODS}

This article will analyze the convention by the use of the convention text, its preparatory works and legal writing. The preparatory works can be accessed through the IMO. ${ }^{1}$

\section{THE NAIROBI CONVENTION}

On the 14th of April 2014 Denmark ratified the Nairobi Convention (IMO, 2015, p. 502). Denmark was the 10th country to ratify the convention and pursuant to art. 18.1 WRC the convention entered into force 12 months afterwards, i.e., on the 14th of April 2015. Currently 25 countries have ratified the convention; among them the United Kingdom, Germany and Liberia (IMO, 2015, p. 506). ${ }^{2}$ In total the merchant fleets of the contracting parties amount to $58.09 \%$ of the gross tonnage of the world's fleet (IMO, 2015, p. 506). It seems likely that the leading shipping nations in Europe will ratify the convention (Baatz, 2014 , p. 267). Within the EU there is also a movement toward ratifications by the Member States. ${ }^{3}$

The Nairobi Convention was negotiated in Nairobi, Kenya between the 14 and 18th of May 2007. As a geographical consequence and as a gesture of appreciation to Kenya for hosting the conference, the convention was named the Nairobi Convention (LEG/CONF.16/INF.6, p. 2). ${ }^{4}$ A convention concerning wreck removal had however been the subject of discussion for a long time. The need for such a convention was recognized already in the 1970 s (Michel, 2007, p. 694)..$^{5}$ This makes the Nairobi Convention the convention that has taken the longest time to develop within the framework of the IMO (Mukherjee and Brownrigg, 2013, p. 327). ${ }^{6}$

\footnotetext{
${ }^{1}$ See docs.imo.org.

${ }^{2}$ The States as of the 16th of October 2015 are Albania, Antigua and Barbuda, Bahamas, Bulgaria, Congo, Cook Islands, Cyprus, Denmark, Germany, India, Iran, Kenya, Liberia, Malaysia, Malta, Marshall Islands, Morocco, Nigeria, Niue, Palau, Panama, Tonga, South Africa, Tonga, Tuvalu, and United Kingdom.

${ }^{3} \mathrm{EU}$ Member States have in a statement in the Council endorsed to ratify the convention. (See Council Document No. 15859/08 ADD 1 of 19/11/2008. Statement by the Member States on Maritime Safety; Ds 2015:16, p. 71).

${ }^{4}$ This was also the first diplomatic conference within the IMO to be held in Africa (LEG/CONF.16/INF.2, p. 2).

${ }^{5}$ This was also highlighted by the then secretary-general of the IMO Efthimios Mitropoulos in his opening statement where he stated that some of the questions being addressed at the conference were already subjects of consideration 35 years ago (LEG/CONF.16/INF.2, p. 1 f.).

${ }^{6}$ This fact also undoubtedly put some pressure on the delegates to actually reach a result. A hint of this pressure is manifested in another part of the then secretarygeneral's opening statement: "[o]nly one test remains, namely, that of your political will to put an end, this week, to more than three decades of expectations" (LEG/CONF.16/INF.2, p. 5).
}

The purpose of the Nairobi Convention is to harmonize the regulations on wreck removal. ${ }^{7}$ The convention is also meant to fill a gap in international law by providing Coastal States with clear mandates of wreck removal when it comes to wrecks situated outside of the territorial sea while at the same time enabling them to claim compensation for incurred costs as a result of the removal [Michel, 2007, p. 694 and cf. Sjöfartsverket (Eng. Swedish Maritime Administration), 2011, p. 34]. Without the convention the mandates of States are unclear when it comes to wrecks located outside of the territorial sea (LEG/CONF.16/INF.2, p. 2 and cf. art. 56 in the United Nations Convention on the Law of the Sea, hereafter abbreviated as UNCLOS). Within the territorial sea however States can apply their national laws on wrecks since the State has full sovereignty in that area. ${ }^{8}$ The situation is not as clear in the exclusive economic zone (Dromgoole and Forrest, 2011, p. 266.). This insecurity results in it being unclear whether the convention codifies already existing mandates that States have according to international law, if it expands the already existing mandates or if it creates new mandates for States in this respect. ${ }^{9}$

\subsection{Area of Application and Definitions 3.1.1. Two Different Types of Wrecks}

The convention distinguishes between two types of wrecks. This is manifested already in the preamble in that State Parties are aware that: "...wrecks, if not removed, may pose a hazard to navigation or the marine environment...". ${ }^{10}$ The convention thus focuses on two situations. The first one involves a wreck posing a hazard to navigation. An example of this is a wreck being positioned in such a way as to obstruct a trafficked fairway. That this may pose a problem is well illustrated by the wreckage of the Tricolor in 2002. Tricolor was a Norwegian-flagged vehicle carrier that sank in a densely trafficked part of the English Channel following a collision with another ship. The wreck was positioned inside the French exclusive economic zone and badly situated in a type of crossing in the traffic separation scheme of the English Channel where the traffic is dense. The wreck was positioned close to the waterline and at times, depending on the tide, submerged close to the surface. Consequently the wreck turned into a hazard to navigation, which was also manifested

\footnotetext{
${ }^{7}$ This was put by Kenya's Minister for Transport, elected as President of the conference, as: "[b]y finally addressing the problem of removal of wrecks, we will be promoting uniformity in international maritime law in a very significant way..." (LEG/CONF.16/INF.3, p. 1).

${ }^{8}$ See art. 2 UNCLOS

${ }^{9} \mathrm{~A}$ similar ambiguity arose in relation to the International Convention Relating to Intervention on the High Seas in Cases of Oil Pollution Casualties from 1969. The convention was an effect of the wreckage of the Torrey Canyon and the environmental effects that followed. In that case the United Kingdom intervened on the high seas and given other States attitudes to and acceptance of this behavior it can be argued that the new convention of intervention only codified already existing provisions of international customary law. The same line of reasoning could potentially be used in relation to the Nairobi Convention (see Dromgoole and Forrest, 2011, p. 94 f.).

${ }^{10}$ These two types of wrecks have been in focus since the formation of the convention. In his opening statement the then secretary-general of the IMO said that a convention on wreck removal had been a priority for several governments for a long time and that: "[t]hese governments clearly saw the removal of wrecks as a task of paramount importance to ensure safe navigation and environmental protection off their coast" (LEG/CONF.16/INF.2, p. 2).
} 
in practice. Even though the wreck was overseen by French authorities and marked in accordance with general practice using buoys and even a radar transponder, a ship collided with the wreck the night after the wreckage. A couple of days later yet another ship collided with the wreck despite surveillance and information of the wreck being spread. ${ }^{11}$

The wreckage of the Tricolor shows the importance of being able to handle wreck removal in cases where wrecks obstruct navigation. In a situation like this immediate action is often necessary. The case also illustrates the uncertainty concerning what actions a State can take when confronted with this kind of situation in its exclusive economic zone. ${ }^{12}$ When the situation emerged French authorities ordered that the wreck should be removed, but doubts were raised as to the mandate to issue that kind of order in accordance with international law (Dromgoole and Forrest, 2011, p. 93.). It is this kind of uncertainty that the Nairobi Convention is meant to eliminate.

The other situation is a wreck that poses a hazard to the environment. An example of this is a ship where the wreckage in itself is a danger to the environment where no other convention or regulation has already regulated the matter. ${ }^{13}$

\subsubsection{The Convention Area}

The Nairobi Convention is applicable in what is called the Convention area. This is defined in art. 1.1 WRC as: “...the exclusive economic zone of a State Party, established in accordance with international law..." This wording is used since a State must claim an exclusive economic zone (Dixon, 2007, p. 215). If a State has not established an exclusive economic zone the convention will, according to art. 1.1 WRC, cover "... an area beyond and adjacent to the territorial sea of that State determined by that State in accordance with international law and extending not more than 200 nautical miles from the baselines from which the breadth of its territorial sea is measured." This coincides with the definition of the exclusive economic zone in art. 57 UNCLOS.

The fact that the Convention area is equal to the exclusive economic zone or a corresponding area means that the convention e contrario is not applicable in the territorial sea, in internal waters or on the high seas. ${ }^{14}$ From the outset the

\footnotetext{
${ }^{11}$ See www.trinityhouse.co.uk/mariner_info/aids_to_navigation/emergency-wreck -marking-buoy.html and (Hamer, 2003).

${ }^{12}$ The above mentioned art. 56 of the UNCLOS allows for measures to be taken by a Coastal State when it comes to the protection of the marine environment.

${ }^{13}$ There are several conventions that may already deal with the environmental aspects of a wreckage; e.g., the International Convention on Civil Liability for Oil Pollution Damage (CLC) and the International Convention on Civil Liability for Bunker Oil Pollution Damage (BUNKER). These conventions are not discussed further here. See also in relation to this art. 4.1 and art. 11 WRC.

${ }^{14}$ There were however suggestions made for a more extensive scope of application. Mexico wanted the definition of an Affected State to be: "... a State in whose Convention area a wreck is located or effect of a maritime casualty are in evidence" (italics added). The purpose of this was to acknowledge effects that a wreck can have at a distance. Probably the delegation envisaged a situation where a wreck is located outside of the exclusive economic zone and thus the Convention area, but that at the same time still affects the State. An example of this would be where tides and currents are transporting emissions from a wreck causing it to pose a hazard to the environment of the State even though the wreck being positioned outside of the Convention area. Mexico did not however have any success with the proposal. That kind of phrasing would de facto mean that the scope of the convention would expand outside of the exclusive economic zone into the high seas. The
}

convention thus covers an area between 12 and 200 nautical miles from the baselines from which the breadth of the territorial sea is measured. ${ }^{15}$ This leads to consequences when it comes to what types of wrecks that are likely to fall under the application of the convention. The water in the exclusive economic zone is often deep. Consequently sunken ships are in general more seldom likely to pose a hazard to navigation, since they will be submerged in such a way as to not cause problems of this kind. Instead it is more likely that the wrecks being covered by the convention in these cases are wrecks that pose a hazard to the environment (Baatz, 2014, p. 266).

Another consequence of the scope of application is that incidents that occur close to shore are not covered. This is problematic since most wreckage occurs close to shore either in the territorial sea [Søfartsstyrelsen (Eng. Danish Maritime Authority), 2012, p. 12; IMO, 2015, p. 11] or in internal waters (Gauci, 2009, p. 211; Luttenberger et al., 2011, p. 2; see also LEG/CONF.16/12, p. 1). To enable an application encompassing these wrecks as well the convention includes an opt-in clause in art. 3.2 WRC allowing a State Party to extend the scope of application to wrecks located within its territory including the territorial sea. The wording used in the article: "[a] State Party may extend the application of this Convention to wrecks located within its territory, including the territorial sea..." indicates that apart from the territorial sea also internal waters are included in the definition. Why would the convention text otherwise explicitly state that the application within the territory also includes the territorial sea? The reasonable construction of that wording is that also other areas than the territorial sea are included and consequently that the application covers internal waters as well. ${ }^{16}$ Of the 25 States that have ratified the convention 13 have chosen to use the opt-in-clause extending the scope of application. ${ }^{17}$ Denmark motivated its use of the clause by stating that an overwhelming majority of wrecks that are likely to be subject to wreck removal will be located within the Danish sea territory. ${ }^{18}$

Usage of the opt-in-clause will furthermore likely result in a shift of balance considering what types of wrecks that will be

Convention area and the Affected State's possibility to take action, and thereby also indirectly the responsibility of the shipowner and the other provisions in the convention, would then vary depending on the current state of the water. Such a scope of application would arguably lead to further uncertainty and problems of interpretation. It would also be hard to reconcile with the general demand on law being predictable and foreseeable.

${ }^{15}$ It can be noted that this fact may lead to the convention actually being applicable on the high seas. The scope of application is 200 nautical miles from the baselines also for States that have not established an exclusive economic zone. In these cases the area between 12 and 200 nautical miles that corresponds to the definition of the exclusive economic zone in the UNCLOS would in fact represent the high seas according to international law and thus coincide with the Convention area (see Dromgoole and Forrest, 2011, p. 99).

${ }^{16} \mathrm{Gauci}$ is also of the opinion that the opt-in clause involves both the territorial sea and internal waters. (See Gauci, 2009, p. 210).

${ }^{17}$ The States are as of the 16 October: Albania, Antigua and Barbuda, Bahamas, Bulgaria, Cyprus, Denmark, Kenya, Liberia, Malta, Marshall Islands, Niue, Panama, and United Kingdom (IMO, 2015, p. 507 f.).

${ }^{18}$ The Danish line of reasoning is that since it is of Danish interest that as many wrecks as possible are covered with insurance, it is also natural to extend the convention's application to also cover Danish sea territory. (See Søfartsstyrelsen (Eng. Danish Maritime Authority), 2012, p. 12). 
covered by the convention. In the territorial sea and internal waters the water is generally more shallow and, as a consequence, more wrecks are likely to pose a hazard to navigation than should the convention only be applicable in the exclusive economic zone.

Considering that wreckage is most likely to occur close to shore and the fact that only roughly half of the Contracting States have chosen to use the opt-in-clause, it is clear that this development is a problem for the convention's effect in practice. ${ }^{19}$ The fact that many States have chosen to not extend the application of the convention also means that the overall goal of striving toward harmonization is undermined. Harmonization and a strive toward a uniform framework are fundamental parts of the preamble to the convention, making the construction with an optional clause of application somewhat bewildering. The inclusion of the opt-in-clause has also been criticized on this basis. As is often the case in international conventions the clause was the result of a compromise between States and organizations that argued for a more extended application and others who were in favor of a more confined area of application. ${ }^{20}$

The opt-in-clause can be seen as an incentive for States to extend the convention's scope of application. It is in this light that the provision should be viewed. Some have however stated that the provision as a compromise seems a bit ambiguous and unnecessary, since the States in favor of an extended scope of application can enact corresponding provisions within their own jurisdictions (Irving, 2010, p. 84 and see also Luttenberger et al., 2011, p. 3). This argument was however addressed in a statement concerning the opt-in-clause issued by Australia, Canada, Germany, Norway, Portugal, and the United Kingdom during the conference. According to the States it would not be possible for a State to unilaterally legislate when it comes to the financial provisions of the convention and the provisions handling compulsory insurance and the ability to claim the insurer directly (LEG/CONF.16/12, p. 1). ${ }^{21}$ This seems to be the better view. A State would without an opt-in-clause have difficulties unilaterally claiming an insurer situated in another State in accordance with the convention text should the other State only apply the convention within the context of the Convention area as described in the convention and should the convention not enable an extension of the scope of application.

There is however some uncertainty as to if this should be possible at all. In a statement issued by the United States at the conference it is stated that it is, according to the view of the United States, still unclear what a State that has chosen to apply the convention on its territory can demand when it

\footnotetext{
${ }^{19}$ If more States would use the opt-in-clause this could also trigger a vitalized discussion of the right to a place of refuge for ships in distress. In that case there would be insurance cover when it comes to ships that are in danger of sinking within a State's territorial sea or internal waters. This would arguably make States more willing to grant places of refuge for ships in distress instead of refusing or rejecting the ship. The sinking of the Prestige shows that the latter can have disastrous effects (See Lahmer, 2008, p. 180).

${ }^{20}$ In the opening statement of the then secretary general of the IMO, the question of extending the convention to the territorial sea was described as a key issue to handle during the conference: “... I am aware that the Conference will still have to decide on some key points, most specifically whether to extend the convention's provisions to the territorial sea" (LEG/CONF.16/INF.2, p. 3).

${ }^{21}$ These issues will be dealt with further below.
}

comes to ships from other States that have not used the opt-inclause. According to the United States a State that has used the opt-in-clause should not be able to apply the convention when it comes to other State Parties that have not used the opt-inclause themselves when a ship e.g., is using its right of innocent passage through the territorial sea. This should instead only be done when the ship is calling a port (LEG/CONF.16/15, p. 1). The background to that statement is a State's right of innocent passage through the territorial sea of another State according to art. 17 UNLCOS. One could argue that the right of innocent passage to some degree has been restricted in a case where a State that has extended the application of the convention takes action in accordance with the provisions in relation to a ship whose Flag State has chosen not to use the opt-in-clause. This seems to contradict the wording in art. $16 \mathrm{WRC}$ where it is stated that: "[n]othing in this Convention shall prejudice the rights and obligations of any State under the United Nations Convention on the Law of the Sea, 1982, and under the customary international law of the sea." There are thus different opinions as to the possibility of applying the convention in this respect.

\subsubsection{Definition of Ship}

A ship is defined in art. 1.2 WRC as "... a seagoing vessel of any type whatsoever..." It is not clear how the term seagoing is to be construed. This requisite was not present in the original draft of the convention (LEG/CONF.16/3, p. 1.). The term is however present as a suggestion in a proposal on the scope of the convention issued by Australia, Canada, Germany, Norway, Portugal and the United Kingdom at the conference (LEG/CONF.16/12, p. 2 ff.). In English case law the term has perviously been construed as not encompassing ships that cannot navigate on the ocean (Rainey, 2013, p. $50 \mathrm{ff}$.). Gauci is of a similar opinion and contends that the term seagoing excludes ships navigating solely on rivers (Gauci, 2009, p. 206). This would affect ships navigating on trade routes along rivers in internal waters. Usually this will be in form of barges of different kinds. ${ }^{22}$ It is however unclear if this is the meaning the term has in the present convention. There are cases in English case law where barge-like structures without propulsion have been considered ships (Gauci, 2009, p. 206). A more extended construction of the term would be that seagoing basically means that the ship can be navigated on water.

The article furthermore includes an enumeration of what kinds of ships that are encompassed in the article. It is stated that hydrofoil boats as well as air-cushion vehicles and submersibles are included in the definition. Submersibles will however to a large extent be warships and on that ground excluded from the application of the convention pursuant to art. 4.2 WRC. $^{23}$ The two last examples in the enumeration are floating craft, with a somewhat unclear scope and meaning, and floating platforms.

\footnotetext{
${ }^{22}$ The traffic on internal waters is of importance in some parts of Europe, e.g., in the Netherlands, Germany and Belgium. There is also a strive toward extending the traffic on internal waters within the EU since it is deemed to be a sustainable means of transportation (See e.g., Trafikanalys Analysis, 2012, p. 23 ff.).

${ }^{23}$ A State Party can however extend the scope of application to also include the State's own warships in accordance with art. 4.3 WRC.
} 
In all of these cases the underlying demand on the vessels being seagoing has to be fulfilled. The two latter examples are furthermore not considered ships while they are "... on location engaged in the exploration, exploitation or production of seabed mineral resources." In this way a large part of the off shoreindustry's vessels are excluded while in service.

\subsubsection{Definition of Wreck and Maritime Casualty}

The convention conjoins the term wreck with the occurrence of a maritime casualty. According to art. 1.3 WRC a maritime casualty is "... a collision of ships, stranding or other incident of navigation, or other occurrence on board a ship or external to it, resulting in material damage or imminent threat of material damage to a ship or its cargo". ${ }^{24}$ This is undoubtedly a wide definition and it is hard to envisage a situation where a wreckage could take place that is not at the same time the result of a maritime casualty as defined.

As a consequence of a maritime casualty the ship can become a wreck. A definition of wreck is found in art. 1.4 WRC where it is stated that a wreck is a sunken or stranded ship (art. 1.4.a); or any part of a sunken or stranded ship, including any object that is or has been on board such a ship (art. 1.4.b); or any object that is lost at sea from a ship and that is stranded, sunken or adrift at sea (art. 1.4.c); or a ship that is about, or may reasonably be expected, to sink or to strand, where effective measures to assist the ship or any property in danger are not already being taken (art. 1.4.d). As can clearly be seen the definition of wreck is broad in the convention. Apart from ships that have stranded or sunk also objects that were on board are covered by the convention. By art. 1.4.c WRC this is extended to encompass objects that have been lost overboard even though the ship in itself has not become a wreck. Floating containers will fall under this part of the definition (Herbert and Lloyd's, 2013, p. 37). Such items by themselves are thus considered wrecks according to the convention. The last section of art 1.4 WRC extends the term wreck to instances where the ship has not yet sunk or stranded but where the ship may reasonably be expected to sink or strand and where effective measures to assist the ship or any property in danger are not already being taken. This last segment of the definition opens up complicated questions of when a ship is to be considered a wreck or not. How those judgements are to be made is unclear. It is also unclear who is going to make them and on what grounds.

\subsubsection{Which Wrecks Are Encompassed by the Convention?}

A question that was debated during the conference was which wrecks that fall under the scope of the convention. The United States criticized the wording of art. 2 that describes a State's right to take measures when it comes to a wreck that constitutes a hazard in accordance with the convention in the Convention area. The fact that the article does not clearly state that it deals with a wreck from another State Party suggests that the rights of States not being parties to the convention are compromised. The United States pointed out the fact that measures that a State can take within the exclusive economic zone toward a

\footnotetext{
${ }^{24}$ This is the same definition as found in art. 221.2 UNCLOS.
}

wreck from another State, are limited according to international customary law as reflected in the UNCLOS. ${ }^{25}$ Art. 221.1 in the UNCLOS states that Coastal States have the right to take and enforce measures beyond the territorial sea provided that they are proportionate to the actual or threatened damage to protect their coastline and other interests enumerated in the article from pollution or threat of pollution following upon a maritime casualty or acts relating to such a casualty, which may reasonably be expected to result in major harmful consequences. The Nairobi Convention however seems to extend the possibility of Coastal States given the fact that the phrasing in art. 2.1 WRC covers wrecks in general. The convention allows a Coastal State to take measures toward a wreck that constitutes a hazard to navigation. This has no corresponding provision in the UNCLOS. The United States proposed that it should be included in art. 16 WRC that nothing in the convention shall prejudice the rights and obligations of non-State Parties to the convention under the UNCLOS and under customary international law of the sea (see LEG/CONF.16/6, p. 1 ff.). The text of the convention was however not modified in the way the United States suggested and the question posed therefore remains unanswered. How the convention deals with wrecks from States that are not parties to the convention is therefore unclear to a certain extent. A construction would be that it follows from art. 16 WRC that the provisions in the Nairobi Convention have no effect should they differ from international customary law when it comes to States not being members of the convention. On the other hand it is curious that the text of the convention did not specifically point toward States not being members of the convention considering the fact that the convention undoubtedly results in changes for the State Parties compared to what would otherwise have been the case in accordance with the UNCLOS and international customary law. In light of this art. 16 WRC seems to refute itself. $^{26}$

\subsection{When and How can a State Take Action?}

As already mentioned art. 2 WRC enables a State Party to take measures in accordance with the convention when it comes to wrecks situated within the Convention area that constitute a hazard. The phrasing "[a] State Party may take measures" (italics added) indicates that there is no obligation for a State Party to act but merely a possibility. A hazard is defined in art. 1.5 WRC as "... any condition or threat that: (a) poses a danger or impediment to navigation; or (b) may reasonably be expected to result in major harmful consequences to the marine environment, or damage to the coastline or related interests of one or more States." This is connected with the wording in the preamble on wrecks posing threats to navigation or the environment. Thus, it is enough that a wreck poses a threat to navigation for a hazard to exist according to the convention. More is needed when it comes to a hazard to the environment. In

\footnotetext{
${ }^{25}$ That the United States based this argument on a provision in the UNCLOS is interesting since the United States has been one of the major opponents to that convention and one of the few larger nations that have not ratified it (See further Dixon, 2007, p. 208).

${ }^{26} \mathrm{Cf}$. the statement by the United States in LEG/CONF.16/15, p. 2.
} 
order for such a hazard to exist there has to be a situation that may reasonably result in major harmful consequences to the marine environment. As already stated this wording is virtually the same as in art. 221.1 UNCLOS. The phrasing suggests that there needs to be damage to a substantial degree. Undoubtedly the phrasing requires qualified judgments to be made. It may be hard to predict when a situation may reasonably be expected to result in major harmful consequences to the marine environment. This criticism was also put forward by Mexico at the conference. The State held that the usage of a word like reasonable might lead to problems when it comes to construction and application since it allows individual State Parties on their own to decide what is needed for the provision to be applicable. In this way the phrasing, according to Mexico, invites States to discretionary decide whether a hazard exists or not based on whether this is suitable for the State. Thus, the wording invites subjective constructions instead of allowing the application to be based on an objective test as to whether a hazard in light of the convention exists or not (LEG/CONF.16/4, ANNEX, p. 1).

Furthermore, a distinction seems to be made in the wording of the article by the words "..., or damage to...," which suggests that there is no need for major harmful consequences for the following segment of the article. The article could however also be construed the other way around which would require the need for such consequences for the whole segment. This is unclear. This part of the article deals with damages to coastlines or other related interests of one or more States.

The related interests are regulated in art. 1.6 WRC. According to the definition these are "interests of a Coastal State directly affected or threatened by a wreck." This is followed by examples of what constitutes related interests e.g., fishing, tourism, health and offshore as well as underwater infrastructure. It should be noted that only States that are Coastal States seem to have these interests according to the convention. By using the term Coastal States a distinction is made between those States that have coasts and State Parties encompassing all States being members of the convention. This suggests that Landlocked States, i.e., States that have no coasts, cannot have the interests in the convention. That view is however not unambiguous since Landlocked States may have the right to fish in the exclusive economic zone of other States in certain cases and also have the right to construct underwater infrastructure in the form of underwater cables and the like. ${ }^{27}$

Apart from the general definition of hazard in art. 1.5 WRC certain criteria are enumerated in art. 6 WRC. The Affected State should take these into account when determining if there exists a hazard in light of the convention or not. These correspond to the ship as such, e.g., its size and construction (art. 6.a WRC). Further criteria deal with geographical circumstances. Thus, the depth of the water on the site of the wreckage can be of importance as well as the tidal movements (art. 6.b-c WRC). There are furthermore criteria that deal with the maritime traffic in the area. Consequently closeness to fairways and traffic separations schemes may affect the question as well as how dense and frequent the traffic is (art. 6.e-f WRC). Also ship-specific

\footnotetext{
${ }^{27}$ See art. 69 , part X and art. 58 UNCLOS.
}

information like what cargo the ship is carrying is of interest as well as what kind of oils that are present on board (art. 6.h WRC). ${ }^{28}$

When it has been determined that there exists a hazard according to the convention the Affected State, according to art. 2.2 WRC, has the right to take measures proportional to the hazard. This demand of proportionality is elaborated in art. 2.3 WRC with the phrasing that these measures cannot go further than what is reasonably necessary in order to remove the wreck. The measures shall furthermore stop as soon as the wreck has been removed and not unnecessarily come into conflict with the rights and interests of other States including the State whose flag the ship had and the persons, legal or physical, that are affected.

\subsection{Measures to Report, Locate and Mark a Wreck}

\subsubsection{Reporting Wrecks}

Pursuant to art. 5 WRC a State Party shall require the master and the operator of a ship flying its flag to report to the Affected State without delay when that ship has been involved in a maritime casualty resulting in a wreck. The Affected State is defined in art. 1.10 WRC as that State in which convention area the wreck is located. It is sufficient that either the owner or the operator reports the incident. The operator of the ship is defined in art. 1.9 WRC as "the owner of the ship or any other organization or person such as the manager, or the bareboat charterer, who has assumed the responsibility for operation of the ship from the owner of the ship and who, on assuming such responsibility, has agreed to take over all duties and responsibilities established under the International Safety Management Code, as amended." The report shall include what is stated in art. 5.2 WRC. This includes information concerning the ship's registered owner and what is necessary in order for the Affected State to determine if the wreck constitutes a hazard according to the convention. The enumeration in the article includes the precise location of the wreck, its type, size and construction and furthermore what kind of damage that has occurred and the condition of the wreck. Information concerning what cargo the ship carries is also relevant and in particular if it includes any hazardous and noxious substances as well as information on different oils, including bunker oil and lubricating oil, on board the ship. It can be noted that the enumeration correlates with the criteria that are to be taken into account according to art. 6 WRC when the Affected State determines if the wreck constitutes a hazard in light of the convention.

\subsubsection{Locating and Marking Wrecks}

When the Affected State becomes aware of a wreck it shall use all practicable means to warn mariners and the States concerned of the nature and location of the wreck as a matter of urgency pursuant to art. 7.1 WRC. Given the wording in art. 7.2 WRC it follows indirectly that this is the case regardless of the wreck being considered a hazard in light of the convention or not. If the State has reason to believe that the wreck poses a hazard it shall

${ }^{28}$ See art. 6 for all criteria. 
ensure that all practicable steps are taken to establish the precise location of the wreck in accordance with art. 7.2 WRC.

When an Affected State has determined that a wreck constitutes a hazard in light of the convention it shall ensure that all reasonable steps are taken to mark the wreck pursuant to art. 8.1 WRC. The phrasing of this passage differs from art. 7 WRC in the sense that art. 8 WRC is only relevant if the wreck has been determined to constitute a hazard. This seems to follow a pattern or method where the Affected State first is informed about the wreck in accordance with art. 5 WRC. Thereafter, the Affected State shall warn those who are at risk and also locate the wreck if the Affected State has reason to believe that the wreck constitutes a hazard. Finally, follows the marking of the wreck when it has been located and determined to pose a hazard.

When marking a wreck the Affected State shall according to art. 8.2 WRC take all practicable steps to ensure that the markings conform to the internationally accepted system of buoyage in use in the area where the wreck is located. In 2006 the IMO recommended the testing of a new kind of buoy specifically used for wrecks (IMO, 2006, p. 1 ff.). This is called an emergency wreck marking buoy and it is designed to facilitate navigation both visually and by radio. The buoy shall be placed as close to the wreck as possible alternatively around the wreck in a pattern and within other marks that are used. The buoy is colored in vertical stripes of blue and yellow and has a top mark in the form of a standing or upright yellow cross (IMO, 2006, ANNEX p. 3). The marking of the wreck shall in accordance with art. 8.3 WRC be promulgated by the Affected State by nautical publications and the like.

\subsection{The Owner's Responsibility}

\subsubsection{Measures to be Taken}

When the Affected State has determined that there is a wreck constituting a hazard in light of the convention the State shall according to art. 9.1.a WRC immediately inform the State of the ship's registry and the registered owner. The responsibility to remove the wreck rests with the registered owner according to art. 9.2 WRC. The registered owner is defined in art. 1.8 WRC as "the person or persons registered as the owner of the ship or, in the absence of registration, the person or persons owning the ship at the time of the maritime casualty." The responsibility is thus channeled toward the registered owner. It should be noted here that it is the time of the wreckage that is decisive when it comes to the question of ownership should there be no registration. A subsequent sale of the ship does not shift responsibility to the new owner in this case.

A removal is defined in art. 1.7 as “... any form of prevention, mitigation or elimination of the hazard created by a wreck." Thus, it is not evident that the removal carried out as a consequence of the convention will be an actual wreck removal. It is sufficient that the measures being taken prevent, mitigate or eliminate the hazard that the wreck creates. Considering the expense of wreck removal operations there might be other more costeffective measures available that fulfill the demands of preventing, mitigating and eliminating the hazard without actually removing the wreck in toto.
The registered owner has the right to contract with any salvor or other person to remove the wreck according to art 9.4 WRC. The Affected State can however lay down certain conditions for the removal but only to the extent necessary to ensure that the removal proceeds in a manner that is consistent with considerations of safety and protection of the marine environment. When the removal has begun the Affected State may only intervene, according to art. 9.5 WRC, to the extent necessary to ensure that the removal proceeds effectively in a manner that is consistent with considerations of safety and protection of the marine environment.

As stated above the owner shall remove the wreck. There may however be cases where the owner objects to this responsibility or cannot be contacted. In order to deal with such situations the Affected State shall, according to art. 9.6.a WRC, set a reasonable deadline within which the wreck is to be removed. The length of this deadline is to be set taking into account the hazard that the wreck poses. Furthermore, the Affected State shall pursuant to art. 9.6.b WRC inform the registered owner in writing of the deadline and specify that should the owner not remove the wreck within the time period the Affected State may remove it at the registered owner's expense. Finally the Affected State shall according to art. 9.6.c WRC inform the registered owner in writing that the State intends to intervene immediately should the hazard become particularly severe. Should the owner not be successful in removing the wreck within the deadline or if the owner cannot be contacted the Affected State can commence the wreck removal according to art. 9.7 WRC by the most practical and expeditious means available provided that it is consistent with considerations of safety and protection of the marine environment. The Affected State may commence the removal prior to this according to art. 9.8 WRC if immediate action is required provided that the State of the ship's registry and the registered owner have been informed. Thus, it would seem that art. 9.8 WRC is not applicable should it be impossible to contact or locate the owner.

\subsubsection{The Cost of the Wreck Removal}

The registered owner is according to art. 10.1 WRC liable for the costs incurred for locating, marking and removing the wreck in art. 7-9 WRC. Making the registered owner liable follows the same pattern as in other conventions of maritime law like the CLC on oil pollution damage (Irving, 2010, p. 207). An interesting aspect of the phrasing in art. 10.1 WRC is however that the liability only seems to encompass costs that the Affected State has incurred. E contrario this would mean that costs incurred by another actor than the Affected State are not covered (see Gauci, 2009, p. 210). The owner has strict liability in the sense that the owner is presumed to be liable. The owner can however be exonerated on three grounds. According to art. 10.1.a WRC the owner is exonerated if the owner proves that the maritime casualty that caused the wreck was the result of an act of war, hostilities, civil war, insurrection, or a natural phenomenon of an exceptional, inevitable and irresistible character. These are standard cases of exoneration in international conventions. It should be noted that it has been argued that acts of terror are not included in acts of war (Gard, 2014, p. 2). Moreover, 
given today's modern technology and the possibility of weather forecasting it is hard to envisage a natural phenomenon being exceptional, inevitable and irresistible. ${ }^{29}$ Furthermore, the owner can be exonerated by art. 10.1.b WRC if the owner proves that the maritime casualty was wholly caused by an act or omission done with intent to cause damage by a third party or according to art. 10.1.c WRC by the negligence or other wrongful act of any Government or other authority responsible for the maintenance of lights or other navigational aids in the exercise of that function. Also these follow what is usually included in maritime law conventions.

\subsubsection{The Owner's Right to Limit Liability}

According to art. 10.2 WRC nothing in the convention affects the registered owner's right to limit liability under any applicable national or international regime. In the article the Convention on Limitation of Liability for Maritime Claims (LLMC) amended by the protocol of 1996, which is the major convention on this area, is expressly mentioned. The convention has broad coverage and will be the convention that in general is applicable when it comes to limitation according to the Nairobi Convention (see IMO, 2015, p. 369 ff.). It is therefore of paramount importance to underline that the LLMC includes an opt-out clause concerning limitation of liability for wreck removal. ${ }^{30}$ Many States chose to use this opt-out clause and the registered owner will thus not be able to limit liability in these States even though the phrasing in the Nairobi Convention might seem to suggest that (Herbert and Lloyd's, 2013, p. 9). The protocol of 1996 did not affect this question. The United Kingdom has for example made a reservation in this case (Hill, 2003, p. 402; Mukherjee and Brownrigg, 2013, p. 328 and see also Gauci, 2009, p. 215 f. for a line of reasoning of why such a reservation is reasonable). The wording in art. 10.2 WRC also enables the registered owner to limit liability according to a national system of limitation of liability but in many cases such a system may not exist.

On the other hand a situation where a State allows for very low limits of liability can be envisaged. This point seems to have been highlighted by Mexico in a proposal at the conference stating that an owner should only be allowed to limit according to a national system of limitation if the limit of liability does not fall below the limit stated in the international conventions on the area and first and foremost the LLMC (see LEG/CONF.16/4, ANNEX, p. 6). Mexico was however not successful in changing the text of the convention and this problem may consequently occur. There are however obvious problems with the proposal put forward by Mexico. The proposal would result in the convention binding States indirectly to international conventions, and in practice to the LLMC, to which the States are not necessarily parties to.

The fact that there may be situations where there is no system of limitation at all was highlighted by the International Group of P\&I Associations (P\&I Clubs) together with the International Chamber of Shipping (ICS) in a statement at the conference. The statement points out that conventions normally include a balance between strict liability, the defenses that the owner can invoke and a possibility to limit liability (LEG/CONF.16/15, p. 2). The fact that there evidently will be differences when it comes to the

\footnotetext{
${ }^{29}$ Tsunamis and the like may arguably fulfill these demands.
}

${ }^{30}$ See art. 18.1 and art. 2.1.d-e LLMC 1976. right to limit liability is in stark contrast with the underlying goal of harmonizing regulations on wreck removal. Considering the large sums of money involved in wreck removal the possibility to limit liability is a question of great significance.

\subsection{Compulsory Insurance}

The Nairobi Convention furthermore contains provisions on compulsory insurance. The registered owner of a ship of 300 gross tonnage and above flying the flag of a State Party is according to art. 12.1 WRC required to have an insurance. Other financial securities, e.g., a bank guarantee, are also allowed. The insurance or security shall cover liability under the convention in an amount that equals the limits of liability under the applicable national or international limitation regime. In all cases the amount shall however not exceed the limitation-amount calculated in line with art. 6.1.b in the LLMC as amended by the protocol. This will e.g., be the case for the States that have chosen to opt-out of limitation for wreck removal in the LLMC. Furthermore, a certificate attesting that insurance or other financial security is in force shall be issued to each ship in accordance with art. 12.2 WRC. This certificate shall show that the ship fulfills the demands that follow from art. 12.1 WRC. An enumeration of what is to be stated in the certificate is found in art. 12.2.a-g WRC. The certificate is to be kept on board the ship according to art. 12.5 WRC.

An important inclusion in the convention when it comes to questions of insurance is furthermore that the costs incurred by a removal according to art. $12.10 \mathrm{WRC}$ can be claimed directly from the insurer or the person that provides financial security. The insurer can then, more or less, use the same defenses as the registered owner. The insurer can also limit liability and the right to limit is not dependent on the owners right to do so. An insurer or other person providing security can furthermore also invoke the defense that the maritime casualty was caused by the willful misconduct of the registered owner.

An interesting provision when it comes to the compulsory insurance is art. 12.12 WRC that states that a State Party shall ensure, under its national law, that insurance or other security is in force in respect of any ship of 300 gross tonnage and above, wherever registered, entering or leaving port in its territory, or arriving at or leaving from an offshore facility in its territorial sea. The wording means that this is to be the case no matter where the ship is registered, i.e., even for ships registered in States that are not parties to the convention. This is controversial given the fact that the convention in this way also affects States that are not parties to the convention. ${ }^{31}$ A reasonable argument in support of this construction is that compulsory insurance for ships from States not parties to the convention is only needed for ships that call at a port or offshore facility in the territorial sea (see Michel, 2007, p. 695 f.). In those cases the State has full sovereignty.

The wording in art. 12.12 WRC concerns the same problems as art. 2.1 WRC that seems to encompass all wrecks that are situated in the Convention area. The phrasing of art. 12.12 WRC in the original draft from the drafting committee had another wording than the one in the convention. At the drafting stage

\footnotetext{
${ }^{31}$ Cf. art. 34 in the Vienna Convention on the Law of Treaties that states that a treaty cannot create rights or obligations for a third State without that State's recognition.
} 
the article read: "[a] State Party shall not permit any ship entitled to fly its flag to which this article applies to operate at any time unless a certificate has been issued...." In the same way as with art. 2.1 WRC the United States criticized the phrasing with the argument that it infringed on the rights of Sates not members of the convention. The original wording required certificates of insurance to be present for a State Party to allow ships from other States not members of the convention to navigate in the Convention area, cf. the wording "operate at any time." This, argued the United States, was in conflict with international customary law (LEG/CONF.16/7, p. 1 f.). The argument was not elaborated further but such a wording would reasonably be in conflict with the right of free passage in another State's exclusive economic zone according to art. 58.1 and art. 87 UNCLOS as well as the right of innocent passage through a State's territorial sea according to art. 17 UNCLOS provided that the State has used the opt-in clause. On this point the United States was successful and art. 12.12 WRC was changed accordingly and thus demanding the process of calling at a port or offshore facility in order for insurance to be compulsory. It also follows indirectly from the statement issued by the United States that such a solution was acceptable from their perspective (LEG/CONF.16/7, p. 2).

\subsection{Time Limits}

A claim for costs incurred as a result of measures taken in accordance with the convention shall according to art. 13 WRC be brought within 3 years from the date "when the hazard has been determined in accordance with this convention." This probably infers to when the Affected State has determined the wreck to constitute a hazard. ${ }^{32}$ There is furthermore a general time limit on 6 years counted from the time of the maritime casualty causing the wreck. The Affected State must act within these 6 years in order to recover costs. If the maritime casualty consists of a series of events the 6 year period is counted from the first event in the series. These time limits seem to exclude the possibility of applying the convention on most of the already existing wrecks (Søfartsstyrelsen (Eng. Danish Maritime Authority), 2012, p. 12 and see also Gauci, 2009, p. 8). ${ }^{33}$ Instead the convention focuses on future wrecks.

\subsection{Settlement of Disputes}

Settlements of disputes are handled in art. 15 WRC. Should a dispute arise between two or more State Parties regarding the interpretation or application of the convention they shall according to art. 15.1 WRC seek to resolve the dispute through negotiation, enquiry, mediation, conciliation, arbitration, judicial settlement, resort to regional agencies or arrangements or other peaceful means of their choice. If a settlement is not reached the provisions on settlement of disputes in the UNCLOS come into effect according to art. 15.2 WRC. There is also a time limit stating that this settlement of disputes shall come into effect if a settlement is not reached within a reasonable period of time. In no instance shall the time period exceed 2 years.

\footnotetext{
${ }^{32}$ See art. 8.1 WRC.

${ }^{33}$ This is also in line with art. 28 in the Vienna Convention on the Law of Treaties stating that a convention does not in dubio have retroactive effect. See however on this topic (Dromgoole and Forrest, 2011), p. $92 \mathrm{ff}$. for a more nuanced view and a discussion on a potential limited application.
}

The provisions on settlement of disputes in the UNCLOS shall be applied whether the individual States are members of the UNCLOS or not. Thus, the application of these rules is extended also to States not members of the convention. The United States harshly criticized this construction of the provision in a statement at the conference. Their view was that no reference at all should be made to the settlement of disputes in the UNCLOS. As a compromise they could accept that the provisions included an opt-out clause through which it would be possible for a State to avoid the provisions on settlement of disputes in the UNCLOS. The United States were however not successful in changing the wording of the article in either of these ways. To include binding provisions on the settlement of disputes in this way is, according to the United States, unique when it comes to conventions within the context of the IMO. The criticism in the statement is clear: " $[\mathrm{t}]$ he United States does not accept that the inclusion of such provision in this Convention, particularly one without an optout provision and adopted under improper procedures, is a precedent for future IMO conventions..." (LEG/CONF.16/18, p. $2 \mathrm{f}$.). This criticism should once again be seen in the context of the United States not being a party to the UNCLOS.

\subsection{Entry Into Force}

According to art. $18 \mathrm{WRC}$ the convention enters into force 12 months following the date on which 10 States have become full members of the convention. Peru criticized the phrasing of this article during the conference. It was at that stage not clear how many State Parties that would be necessary in order for the convention to enter into force. It is however clear from Peru's statement that the State wanted the amount of States necessary also to include a certain percentage of the gross tonnage of the world's merchant fleet. Peru expressed concern over the fact that the convention otherwise was at risk of entering into force after the limit had been reached while the members represented only a tiny amount of the States actually involved in shipping (LEG/CONF.16/9, p. 1 f.). The construction that Peru proposed can be found in other conventions on maritime law, e.g., The Maritime Labor Convention (MLC). ${ }^{34}$ Peru did however not affect the construction of the article and the number of States needed for the convention to enter into force was set to 10 . The United States argued in a statement at the conference that the absence of a criterion based on percentage of the gross world tonnage is hard to reconcile with the need for international acceptance by Flag-States when it comes to the content of the convention. The United States alluded to the convention setting up demands on Flag-States, while it provides extended rights to Coastal- and Port-States. This unbalanced position demands, argued the United States, broad acceptance which a criterion on a percentage of the gross world tonnage would have provided (LEG/CONF.16/15, p. 1).

The demand for 10 States is fairly low. This level can be construed in different ways. One construction is that the low amount of States necessary for the convention to enter into force shows that the final phrasing of the convention gained broad global acceptance at the conference. The time it took for the convention to reach the 10 States necessary on the other

\footnotetext{
${ }^{34}$ See art. VIII MLC.
} 
hand, suggests that this might not have been the case (Irving, 2010 , p. 84). This would indicate that Peru was right. It should however be noted that the United Kingdom as well as the Marshall Islands and Liberia have now ratified the convention. There is also a movement within the EU for Member States to ratify the convention. After the tenth ratification was reached the numbers of ratifications increased quite rapidly and the 25 current ratifications now make up for $58.09 \%$ of the gross tonnage of the world's merchant fleet (IMO, 2015, p. 506).

\section{CONCLUSIONS}

As shown above there are some uncertainties and unclear parts in the convention. There are also advantages and disadvantages with using it as unified framework for wreck removal.

The biggest advantage of the convention is that it provides a uniform regulation of wrecks. It also clearly states the registered owner's responsibility in the case of a wreckage while at the same time enabling the Affected State to act in situations where immediate action is needed. Furthermore, the convention also ensures monetary compensation following wreck removal.

There are however several disadvantages of the convention. A peculiar inclusion is the opt-in clause that allows States to extend the application to the territorial sea and internal waters. This possibility arguably inhibits harmonization which is in direct opposition with the wording in the preamble. As is often the case this was the result of a compromise at the conference. There is

\section{REFERENCES}

Baatz, Y. (2014). Maritime Law. New York, NY: Taylor and Francis.

Dixon, M. (2007). Textbook on International Law. Oxford, UK: Oxford University Press.

Dromgoole, S., and Forrest, C. (2011). The Nairobi Wreck Removal Convention 2007 and hazardous historic shipwrecks. Lloyd's Maritime Commer. Law Q. 1, 92-122.

Gard, (2014). Member Circular No. 08/14. Arendal.

Gauci, G. (2009). The international convention on the removal of wrecks 2007 - a flawed instrument. J. Business Law 2, 203-223.

Hamer, M. (2003). Shipping 'pile-up' sparks safety fears. New Sci. 177, 7.

Herbert, J., and Lloyd's (2013). The Challenges and Implications of Removing Shipwrecks in the 21st Century. London: Lloyd's.

Hill, C. (2003). Maritime Law. Lloyd's Practical Shipping Guides. London: Informa Law from Routledge.

IMO. (2006). Emergency Wreck Marking Buoy. SN.1/Circ.259. London.

IMO. (2015). Status of Multilateral Conventions and Instruments in Respect of which the International Maritime Organization or its Secretary-General Performs Depositary or Other Functions. Available online at: www.imo.org/en/About/ Conventions/StatusOfConventions/Pages/Default.aspx

Irving, W. (2010). The Nairobi Convention: reforming Wreck removal in New Zealand. Aust. N.Z. Maritime Law J. 24, 76-92.

Lahmer, V. (2008). “The 2007 Nairobi International Convention on the removal of wrecks," in Enforcement of International and EU Law in Maritime Affairs, eds P. Ehlers and R. Lagoni Lit (Berlin: Verlag), 149-180.

Luttenberger, A., Rukavina, B., and Rak., L. (2011). "The implementation of the Nairobi Convention on the removal of Wrecks, 2007 in the croatian law," in 14th International Conference on Traffic Science Faculty of Maritime Studies Portoroß (Portorož: University of Ljubljana).

Michel, D. C. (2007). Introductory note to the Nairobi international convention on the removal of wrecks. Int. Legal Materials 46, 694-696. furthermore a lack of uniformity when it comes to limitation. Some States have opted out of the possibility to limit liability when it comes to wreck removal in the LLMC as amended. There may also exist different national regimes in this respect. The convention also includes some unclear and ambiguous articles, e.g., the already mentioned art. 2.1 and art. 16 WRC. Another thing to keep in mind is the definition of removal in the convention which opens up for other measures than an actual wreck removal in toto.

Despite these disadvantages the convention addresses the questions posed in the beginning of this article. It clearly points out the registered owner as the one responsible for the wreckage and the wreck removal. It furthermore states what measures in the form of reporting, locating, marking and removing the wreck that can and are to be taken after a wreckage. Finally, the convention also ensures the possibility of enforcement by compulsory insurance on the behalf of the owner combined with a possibility of claiming the insurer directly.

The deficiencies observed are perhaps a prize one must pay in order to reach a more harmonized regulation. In this way the Nairobi Convention is a step in the right direction toward a unified framework for wreck removal.

\section{AUTHOR CONTRIBUTIONS}

The author confirms being the sole contributor of this work and approved it for publication.

Mukherjee, K. P., and Brownrigg, M. (2013). Farthing on International Shipping. Heidelberg: Springer.

Rainey, S. (2013). What is a ship under the 1952 Arrest Convention. Lloyd's Maritime Commer. Law Q. 1, 50-85.

Sjöfartsverket (Eng. Swedish Maritime Administration). (2011). Miljörisker från fartygsvrak (Eng. Environmental Risks from Shipwrecks). Available online at: www.sjofartsverket.se/upload/vrakutredning/Vrakrapport.pdf

Søfartsstyrelsen (Eng. Danish Maritime Authority). (2012). J.nr. 2012002641, Forslag til Lov om andring af søloven, lov om skibes bescetning, lov om tillag til strandingslov af 10. april 1895 og forskellige andre love samt ophovelse af lov om registreringsafgift for fritidsfartøjer (Gennemførelse af vragfjernelseskonventionen, tilpasninger som følge af passagerrettighedsforordningen, gebyr for sønorings- og kvalifikationsbeviser, indførelse af en årlig afgift for skibe optaget $i$ skibsregistrene og sanktionering af skibsførerens forpligtigelse til at redde de ombordvorende m.v.) (Eng. abbreviation: Proposal to Change the Danish Maritime Code and Implement the Wreck Removal Convention). Copenhagen.

Trafikanalys Analysis. (2012). Godstransporter $i$ Sverige - redovisning av ett regeringsuppdrag (Eng. abbreviation: Report on the Transportation of Goods in Sweden). Rapport (Eng. Report) 2012:7.

Conflict of Interest Statement: The author declares that the research was conducted in the absence of any commercial or financial relationships that could be construed as a potential conflict of interest.

Copyright (C) 2016 Kern. This is an open-access article distributed under the terms of the Creative Commons Attribution License (CC BY). The use, distribution or reproduction in other forums is permitted, provided the original author(s) or licensor are credited and that the original publication in this journal is cited, in accordance with accepted academic practice. No use, distribution or reproduction is permitted which does not comply with these terms. 